\title{
Tracking neonicotinoids following their use as cotton seed treatments
}

Kristina L Kohl ${ }^{1}$, Lauren K Harrell ${ }^{2}$, Joseph F Mudge ${ }^{1}$, Seenivasan Subbiah ${ }^{1}$, John Kasumba ${ }^{1}$, Etem Osma ${ }^{3}$, Apurba K Barman ${ }^{4}$, Todd A Anderson ${ }^{\text {Corresp. } 1}$

1 Department of Environmental Toxicology, Texas Tech University, Lubbock, Texas, United States

2 Texas A\&M AgriLife Extension Service, Wharton, Texas, United States

3 Biology Department, Erzincan Binali Yildirim University, Erzincan, Erzincan Province, Turkey

4 Department of Entomology, University of Georgia, Tifton, Georgia, United States

Corresponding Author: Todd A Anderson

Email address: todd.anderson@ttu.edu

Neonicotinoids are a leading class of insecticides on the global market, accounting for nearly twenty-five percent. They are widely used in both agricultural and residential settings. Causing neuron failure by irreversibly binding to the insect nicotinic acetylcholine receptor, neonicotinoids offer broad spectrum efficacy against a variety of pests. However, because they are non-selective with regards to insect species, there has been some concern with neonicotinoid use over threats to pollinators such as honeybees, and potential indirect effects to migratory waterfowl as a result of invertebrate prey population depletion. In order to study occurrence and fate of neonicotinoids (thiamethoxam and imidacloprid), we analyzed cotton leaves on plants grown from neonicotinoid-treated seeds and corresponding soil samples between cotton rows. Neonicotinoid concentration data from cotton leaves appears to be consistent with the claim that seed treatments protect plants for 3-4 weeks; by 30 days post-planting, neonicotinoid concentrations fell, in general, to $200 \mathrm{ng} / \mathrm{g}$ or lower. This represents about a ten-fold decrease from plant concentrations at approximately two weeks post-planting. It was found that neonicotinoids used as seed treatments remained present in the soil for months post planting and could be available for runoff. To that end, 21 playa wetlands were sampled; ten had at least one quantifiable neonicotinoid present, three of which were classified as grassland or rangeland playas, two were urban, and the remaining five were cropland playas. In several instances, neonicotinoid concentrations in playas exceeded EPA chronic benchmarks for aquatic invertebrates. 
1 Tracking neonicotinoids following their use as cotton seed treatments

2

3 Kristina L. Kohl ${ }^{1}$

4 Lauren K. Harrell²

5 Joseph F. Mudge ${ }^{1}$

6 Seenivasan Subbiah ${ }^{1}$

7 John Kasumba ${ }^{1}$

8 Etem Osma $^{3}$

9 Apurba K. Barman 2,4

10 Todd A. Anderson ${ }^{1 *}$

11

$12{ }^{1}$ Department of Environmental Toxicology, Texas Tech University, Lubbock, Texas, United States

$13{ }^{2}$ Texas A\&M AgriLife Extension Service, Wharton, Texas, United States

$14{ }^{3}$ Biology Department, Erzincan Binali Yildirim University, Erzincan, Erzincan Province, Turkey

$15{ }^{4}$ Department of Entomology, University of Georgia, Tifton, Georgia, United States

16

17 *Corresponding author: todd.anderson@ttu.edu 

nearly twenty-five percent. They are widely used in both agricultural and residential settings.

Causing neuron failure by irreversibly binding to the insect nicotinic acetylcholine receptor, neonicotinoids offer broad spectrum efficacy against a variety of pests. However, because they are non-selective with regards to insect species, there has been some concern with neonicotinoid use over threats to pollinators such as honeybees, and potential indirect effects to migratory waterfowl as a result of invertebrate prey population depletion. In order to study occurrence and fate of neonicotinoids (thiamethoxam and imidacloprid), we analyzed cotton leaves on plants grown from neonicotinoid-treated seeds and corresponding soil samples between cotton rows. Neonicotinoid concentration data from cotton leaves appears to be consistent with the claim that seed treatments protect plants for 3-4 weeks; by 30 days post-planting, neonicotinoid concentrations fell, in general, to $200 \mathrm{ng} / \mathrm{g}$ or lower. This represents about a ten-fold decrease from plant concentrations at approximately two weeks post-planting. It was found that neonicotinoids used as seed treatments remained present in the soil for months post planting and could be available for runoff. To that end, 21 playa wetlands were sampled; ten had at least one quantifiable neonicotinoid present, three of which were classified as grassland or rangeland playas, two were urban, and the remaining five were cropland playas. In several instances, neonicotinoid concentrations in playas exceeded EPA chronic benchmarks for aquatic invertebrates. 

spectrum of agricultural and residential applications (Jeschke et al. 2011). Application methods vary according to crop, but many are used as seed treatments (seed coatings). Neonicotinoids are moderately persistent in the environment; half-lives in soil typically range from a few weeks to several months (Sharma and Singh, 2014), but can be much longer according to field studies (Morrissey et al. 2015). In aquatic systems, some neonicotinoids are susceptible to photolysis with half-lives as short as 1-2 days (Bonmatin et al 2015), however, natural waters are usually turbid so these half-lives may be much longer.

Possible non-target consequences to pollinator species, particularly honeybees, as a result of neonicotinoid application have been a concern and focus of research to date (Krupke et al. 2012; Tsvetkov et al. 2017; Samson-Robert et al. 2017). A possible link between unintentional pollinator death and neonicotinoid use has resulted in restrictions on neonicotinoid applications in Europe (Maxim and van der Sluijs, 2013). Initially, use of thiamethoxam, clothianidin, and imidacloprid was restricted on crops "attractive to bees" across the European Union, but in 2018 that restriction was expanded to include all outdoor uses; thiamethoxam, clothianidin, and imidacloprid can only be applied in greenhouses.

Effects on pollinators are not the only concerns related to neonicotinoid use. Recently, potential dangers to aquatic invertebrates in wetlands have become an additional area of research focus (Finnegan et al. 2017). Subsequent indirect threats to more charismatic aquatic and terrestrial organisms as a result of impacts to aquatic invertebrates are of research interest 
63 reduced aquatic invertebrate populations has been observed (Hallmann et al. 2014), however

64 the potential impact on other species, such as migratory waterfowl, is less known.

Use of neonicotinoid seed treatments is gaining popularity due to increased selectivity for certain pests, long-term protection, and reduced use of active ingredient. It has been suggested that the use of neonicotinoids as a seed treatment, rather than as a drip treatment or foliar application may reduce some of the threat to pollinators, although this assertion is heavily debated (Tomizawa and Casida 2005; Hodgson and Krupke, 2012; Girolami et al. 2009; Huff Hartz et al. 2017); the negative impact of neonicotinoids on insect parasitoids and natural enemies has limited their use in IPM programs.

When applied to the seed, a portion of the active neonicotinoid ingredient is translocated, via the vascular tissue (xylem), throughout the whole plant, offering protection against piercingsucking insects (Girolami et al. 2009; Goulson 2013). Movement of neonicotinoids from the treated seed to the surrounding soil also occurs and is a function of irrigation and water movement within the soil (Sanchez-Bayo et al. 2007). As the biomass of the plant increases over the growing season, the concentration of neonicotinoids in the plant decreases (Balfour et al. 2016). Seed treatments are typically purported to protect the plant from target pests for 3-4 weeks after emergence (Maienfisch et al. 2001).

Cotton is an important crop in Texas, and specifically in the Southern High Plains (SHP) region. Neonicotinoid seed treatments are well suited for cotton, because they offer broad spectrum protection against many sucking insects, such as thrips and aphids, which are common early season cotton pests (Elbert et al. 2008; Maienfisch et al. 2001). As such, neonicotinoids (particularly imidacloprid and thiamethoxam), applied as seed treatments and via other 
85

86

87

88

89

90

91

92

methods, are widely used across the SHP. In a region like the SHP, where agriculture can be a risky undertaking due to weather conditions and a shorter production window, offering extra protection from pests at the beginning of a plants life can be crucial.

In the semi-arid SHP, playa wetlands are the main surface hydrological features. Existing mainly in their own individual watersheds, these dipressional wetlands act as catchment basins for most of the surrounding runoff, including runoff due to rain events and irrigation (Belden et al. 2012); the runoff may contain agrochemicals such as fertilizers and pesticides. Playa wetlands provide important habitat for a host of wildlife, including migratory birds and the aquatic invertebrates they depend on as a food source. Each year, millions of waterfowl, shorebirds, and landbirds winter in or pass through the SHP as part of the Central Flyway. Invertebrate density is a key factor impacting the carrying capacity of a playa for migratory bird populations (Anderson and Smith, 1999).

The initial goal of this study was to determine neonicotinoid (imidacloprid and thiamethoxam) concentrations in soil and cotton leaves as a result of seed treatment use. However, the study also provided opportunities to estimate and assess neonicotinoid runoff from cotton fields when used as seed treatments to playa wetlands.

\section{Materials and Methods}

Cotton leaf and field soil samples were obtained through cooperation with Texas A\&M Agrilife Extension Service. Cotton was cultivated in-field at 5 locations in West Texas; viz. Halfway, Kress, Lamesa, Wall, and Chillicothe. Thiamethoxam and imidacloprid treated seeds were used, with all seed coatings containing approximately $0.25 \mathrm{mg}$ of active ingredient per seed. 
107 Planting occurred in May of 2014 (the exact date varied by location). Four consecutive replicate

108 blocks were grown at each location; each block contained a set of thiamethoxam-treated seeds, 109 imidacloprid-treated seeds, and one or two sets of control seeds grown in rows within the block.

110 The number of rows per treatment within a block varied between three and four, depending on

111 the field. Spaces were left between each block to signify the beginning of a new replicate. Fields

112 were irrigated via center pivot sprinkler (a common practice in the area) and no additional

113 neonicotinoids were applied to the plants throughout the growing season.

Sampling

Leaf samples were collected from plants during the month of June 2014. Chillicothe, Lamesa, and Wall sites were sampled twice; Kress and Halfway were only sampled once. When two samplings occurred, dates of collection were roughly one to two weeks apart. Whole leaves were taken from the plant, bagged and transported to the lab, where they were frozen until analysis. At the first sampling, samples were composites of several small leaves from the same plant in order to have sufficient tissue mass. Subsequent samples consisted of a lone, mature $122\left(5^{\text {th }}\right)$ leaf.

Soil cores were collected in June and at the end of September/beginning of October, 2014. Three sites (Chillicothe, Lamesa, and Wall) were sampled twice, while two sites (Kress and Halfway) were only sampled once. When two samplings occurred, dates of collection were roughly one to two weeks apart. An $11 \mathrm{~cm}$ core of soil was collected at a distance of approximately $15 \mathrm{~cm}$ from a plant perpendicular to the cotton row (the typical distance between 
129 the planted row, the goal was to avoid collecting any un-germinated seeds or remaining seed 130 coatings in the sample. Soils were placed in sample bags, and returned to our laboratory, where 131 they were stored at $-20^{\circ} \mathrm{C}$ until analysis.

Playa water samples were collected in 2014 from 21 playas in the northern region of the Texas SHP. Playas were in watersheds classified as cropland (10 sites), grassland (7 sites), or urban (4 sites). Playas were classified as cropland if they received most of their water from drainage and runoff from agricultural lands currently in use for crop production. Playas that were in rural locations but did not receive runoff from farmed land were classified as grassland. These $\mathrm{mL}$ of water was collected from each playa, in water 15 to $30 \mathrm{~cm}$ deep. The amber sample jars were capped, stored in coolers, and transported back to Texas Tech University, where they were stored frozen until analysis. Cotton leaf samples were allowed to dry for $72 \mathrm{~h}$ between weighings, then roughly cut into small pieces and placed in $15-\mathrm{mL}$ conical tubes with $12 \mathrm{~mL}$ of acetonitrile. To determine dry weight, soil samples were weighed and placed in the hood for 48 hours to dry, then weighed again. The samples were then transferred to $50-\mathrm{mL}$ conical tubes and $25 \mathrm{~mL}$ of acetonitrile added to each sample. All samples were agitated on a shaker table for $2 \mathrm{~h}$. After shaking, samples were left for $24 \mathrm{~h}$, at which point they were centrifuged at $2000 \mathrm{rpm}$ for 10 minutes. As much acetonitrile as possible was decanted from each sample into a $15-\mathrm{mL}$ conical tube and volumes 
151 were recorded. After evaporating to dryness, samples were reconstituted in $1 \mathrm{~mL}$ of 1:1 HPLC-

152 grade acetonitrile and HPLC-grade water. Samples were filtered using syringeless auto-sample 153 vials (0.45 $\mu \mathrm{m}$ glass microfiber filter) and analyzed as described below. Acetamiprid was used as 154 a surrogate spike for quality assurance purposes, as it was not used in the experimental fields 155 and therefore not expected to occur in the leaf and soil samples. Every fifth cotton leaf and soil 156 sample was spiked using a stock solution of acetamiprid in methanol. Spike-recovery tests for 157 neonicotinoids in blank plant and soil samples indicated that extraction efficiency was 158 quantitative and reproducible.

Neonicotinoids were extracted from water samples using solid phase extraction (SPE). A 50-mL water sample was first filtered using a $0.45 \mu \mathrm{m}$ Nylon syringe filter. Burdick \& Jackson $\mathrm{C}_{18}$ SPE cartridges $\left(1000 \mathrm{mg}\right.$ ) were conditioned with $5 \mathrm{~mL}$ of methanol, followed by $5 \mathrm{~mL}$ of Milli- $\mathrm{Q}^{\circledR}$ water. The filtered water samples were passed through the conditioned cartridges and dried under vacuum for 5 minutes. Cartridges were then eluted with $5 \mathrm{~mL}$ of acetonitrile in 1-mL increments. Samples were evaporated to dryness and reconstituted in $0.5 \mathrm{~mL}$ of 1:1 HPLC-grade acetonitrile and HPLC-grade water, then transferred to 2-mL glass vials for HPLC analysis.

Given that the cotton test plots represented a controlled scenario where they were expected to contain known analytes, we used conventional high performance liquid chromatography (HPLC) with UV detection rather than a more definitive technique like liquid chromatography-mass spectrometry (LC-MS) for the soil and plant samples. Analyte concentrations were determined using an Agilent 1100 series HPLC with a UV detector, and a

171 Thermo Scientific BDS Hypersil $C_{18}$ column $(250 \times 4.6 \mathrm{~mm} ; 3 \mu \mathrm{m}$ particle size $)$ for analyte 172 separation. A mobile phase of $70 \%$ water and $30 \%$ acetonitrile was used at a flow rate of 0.5 
$173 \mathrm{~mL} / \mathrm{min}$. All solvents were HPLC grade. Sample injection volume was $25 \mu \mathrm{L}$ and sample run time

174 was 25 minutes. A wavelength of $270 \mathrm{~nm}$ was used for the detection and quantification of 175 imidacloprid; $254 \mathrm{~nm}$ was used for thiamethoxam. In hindsight, we should have also tested for 176 clothianidin, a metabolite of thiamethoxam produced in cotton plants (Nauen et al. 2003). Initially, playa water samples were analyzed with an Agilent 1100 series HPLC-UV using conditions identical to those described above for leaf and soil samples with the exception that clothianidin and acetamiprid were added to the analyte list. Confirmatory analyses were conducted using LC-MS. For those analyses, HPLC parameters were as follows: column - Gemini

$\mathrm{NX}-\mathrm{C}_{18}, 3 \mu$ particle size, $150 \mathrm{~mm}$ length $\times 2 \mathrm{~mm}$ diameter; mobile phase $\mathrm{A}=$ water $+0.1 \%$ formic acid, mobile phase $B=$ acetonitrile $+0.1 \%$ formic acid; mobile phase composition $(A: B, v / v)$ was 100:0 at $0 \mathrm{~min}, 30: 70$ at $3 \mathrm{~min}, 15: 85$ at $6 \mathrm{~min}, 10: 90$ at $9 \mathrm{~min}, 50: 50$ at $12 \mathrm{~min}$, and 100:0 from

14 to $15 \mathrm{~min}$; flow rate $=100 \mu \mathrm{L} / \mathrm{min}$; injection volume $=20 \mu \mathrm{L}$. For MS parameters, we used heated electrospray ionization in the positive mode with selected reaction monitoring. Parent and product ions for thiamethoxam, imidacloprid, acetamiprid, and clothianidin were $292 \rightarrow 211$ and 132, $256 \rightarrow 209$ and 175, $223 \rightarrow 126$ and 56, and $250 \rightarrow 132$ and 169, respectively.

Statistical Analysis

Because we sampled plots in which specific neonicotinoids had been used, residue data from those field plots (soil and plant samples) were normally distributed. We used ANOVA to test for site (location) effects followed by a Tukey's post hoc test. We used simple T-tests to determine effects of time (soil concentration differences between $1^{\text {st }}$ and $2^{\text {nd }}$ sampling point) within a site. Thiamethoxam residue data for playa samples were normally distributed, however, 
195 data for the other neonicotinoids were not normal and followed a typical pattern (logarithmic)

196 for environmental residues where non-detects are frequent. We used ANOVA $(\alpha=0.05)$ to

197 compare thiamethoxam concentrations and/or total neonicotinoids by playa type.

198

199

Results and Discussion

200

Generally, plant and soil sample concentrations were quite variable, even among

201

replicates in the same treatment field for a given sampling date. Detection of treatment

202

compounds was isolated to the respective treatment replicate samples in all instances;

203

thiamethoxam was never detected in samples from imidacloprid-treated plots and vice versa.

204

Neither treatment compound was detected in any soil or plant sample from control plots.

205

206

Cotton Leaves

207

Overall, average cotton leaf concentrations of imidacloprid by site and sampling date

varied from non-detect in all four samples (Wall, 6/23/2014) to $15,100 \mathrm{ng} / \mathrm{g}$ (ppb) (Kress,

6/3/2014) (Table 1). Thiamethoxam averages ranged from 18 ppb (Wall, 6/23/2014; Halfway,

$6 / 11 / 2014$ ) at 30-35 days after planting to > 10,600 ppb (Kress, 6/3/2014) at 20 days after

211 planting.

212

For the sites where cotton leaves were sampled twice, samples were collected no more

213 than 15 days apart, with the final sample collected between one and 1.5 months after planting.

214 In general, concentrations of individual neonicotinoids were similar across all sites, with respect

215 to date of sampling. That is, leaf concentrations at initial sampling were higher than those at

216 subsequent dates. Average thiamethoxam concentrations tended to be slightly higher than 
217 average imidacloprid concentrations when compared by site and date of sampling, suggesting

218 that the more water soluble thiamethoxam is more readily translocated through the plant in 219 xylem. However, we observed a large amount of sample variation (as reflected by the relatively 220 high standard errors among sample replicates), so any data interpretation should be made with 221 that in mind.

Imidacloprid concentrations significantly decreased between the first and second samplings ( $p<0.05$ for all sites). Average concentrations generally fell by an order of magnitude to approximately $250 \mathrm{ppb}$ or less. In the second round of samples, non-detects were frequent; imidacloprid was not detected in any of the second round of samples from Wall. Decreases in thiamethoxam concentrations were significant at two of the three sites: Wall and Chillicothe, but not at Lamesa. While Wall and Chillicothe had similar concentrations to each other at both the first and second samplings, average concentrations at Lamesa were higher at both time points, due to a relatively large variation among the replicates.

Although Halfway was only sampled once, $35 \mathrm{~d}$ after planting, the average concentrations of imidacloprid and thiamethoxam seem to correspond to the values of samples from other sites collected at a similar time since planting (second samplings of Chillicothe, Lamesa, and Wall). Kress was also only sampled once, $20 \mathrm{~d}$ after planting. Average concentrations of both imidacloprid and thiamethoxam at Kress were higher than samples from other locations taken at comparable dates (first sampling of Chillicothe, Lamesa, and Wall). The average imidacloprid concentration in cotton leaves was 7 - 11 times higher at Kress than at the other three sites and

237 the differences were statistically significant; the average thiamethoxam concentration was about 
2382 - 4 times higher at Kress than at Chillicothe, Lamesa, or Wall, although the differences were not

239 statistically significant.

240 When neonicotinoids are applied via seed treatment, and no other applications of

241 neonicotinoids occur, there is a finite amount of active ingredient available to be taken up by a

242 plant. When plants first emerge and biomass is low, the concentration of neonicotinoids is

243 relatively high. As the plant increases in biomass, it effectively dilutes that concentration,

244 resulting in a lower concentration of active ingredient in the plant tissue (Balfour et al. 2016).

245 Based on the locations sampled twice and assuming losses followed a simple linear relationship,

246 the thiamethoxam and imidacloprid dissipation half-lives in cotton leaves were 4.3 days and 4.5

247 days, respectively.

248 Our neonicotinoid concentration data from the cotton leaves appears to be consistent

249 with the claim that seed treatments protect plants for 3-4 weeks (Greenberg et al. 2009); by 30

250 days post-planting, concentrations fell, in general, to $200 \mathrm{ppb}$ or lower (Figure 1). This represents

251 about a ten-fold decrease from concentrations at approximately two weeks post-planting. If

252 concentrations of 5-10 ppb in plant tissue are sufficient to protect against pests, as previously

253 reported (Greenberg et al. 2009), then the duration of protection may extend out to 5-6 weeks.

254

255

Soil

256

All soil samples from treated plots had quantifiable amounts of their respective seed

257 treatment compound (either imidacloprid or thiamethoxam), regardless of treatment, field, or time of sample collection (Table 2). No treatment soil samples had detectable amounts of 
259

260

261

262

263

264

265

266

267

neonicotinoids other than those they were treated with. Neither thiamethoxam nor imidacloprid were detected in any soil samples corresponding to control (untreated seeds) plots.

Comparisons were conducted between average soil imidacloprid and thiamethoxam concentrations across sampling dates at individual sites. Imidacloprid concentrations in Wall were the only ones that decreased, or changed, significantly between sampling dates $(p<0.05)$. Imidacloprid concentrations did not significantly vary with regards to time in Lamesa or Chillicothe. It is important to note that the average soil concentration in Lamesa on 6/10/2014 was much higher than all other imidacloprid samples from comparable sampling dates, due to one extreme (outlier) concentration of $593 \mathrm{ppb}$. Because this concentration is so much higher than any other detected imidacloprid concentration, it seems plausible that a seed casing was collected in the soil core, resulting in an artificially inflated concentration. Even with this high average, there was no statistically significant difference between imidacloprid concentrations in June and September sampling dates.

There was no statistically significant difference in thiamethoxam concentrations with regards to time at Wall, Lamesa, or Chillicothe. The general lack of change in soil neonicotinoid concentrations was expected given the relative high half-lives of imidacloprid and thiamethoxam in soil. It is interesting to note, however, that it was a set of imidacloprid samples that decreased significantly, given that the half-life of imidacloprid in ideal soil conditions is up to 228 days, whereas thiamethoxam's half-life is up to 72 days (Morrissey et al. 2015). September samples were collected approximately 4.5 months post planting, well past the 72 day maximum half-life of thiamethoxam. This lack of expected degradation suggests that the release of neonicotinoids from the seed coating does not happen quickly, but rather slowly as the seed germinates and 
281 then as the seed casing breaks down. Since $80 \%$ of the coating remains in the soil (Goulson 2013),

282 seed treatments could result in accumulation long-term (Jones et al. 2014). Finally, neonicotinoid

283 half-lives determined under controlled laboratory conditions may be different than observed

284 degradation in environmental conditions which also include dissipation "losses" from leaching 285 and runoff.

While neonicotinoid seed-treatments may offer long term protection, it is also important

287 to consider that the soil residue results from our study and others (Jones et al. 2014) show that active ingredient is moving from the seed coating to the soil, and remaining there for months after planting. Less than $5 \%$ of imidacloprid used in cotton seed treatment is taken up by the germinating seed, leaving a significant mass available to move elsewhere (Sur and Stock 2003). The presence of neonicotinoids in soil allows for the movement of those chemicals to other environmental compartments such as surface water (Hladik et al. 2014), through runoff and leaching (Wettstein et al. 2016).

Tier I type assessments of agrochemical runoff are used to estimate worst-case scenarios and assess the potential for ecological threats based on available data. Simple models are frequently used to help accomplish the task of determining whether pesticide concentrations may potentially exceed environmental benchmarks. One screening mechanism, often termed the "Back-of-the-Envelope" calculation, is based largely on the solubility of the chemical. This screening forms the basis of the GENEEC (GENeric Estimated Exposure Concentration) model (Parker et al. 1995) in use today. We used this "Back-of-the-Envelope" calculation to assess neonicotinoid runoff potential when used as seed coatings, supplementing the traditional 
302 watershed/pond characteristics for those more relevant to SHP cotton agriculture, watersheds, 303 and playa wetlands.

304 Estimates of playa area, depth, watershed (runoff) size, cotton seed drop rate, and active 305 ingredient per seed, as well as compound solubility were needed for the model. Values of 6.3 306 hectares for playa area and 55.5 hectares of runoff were used, based on the average playa size 307 in the SHP and average playa watershed size (Haukos and Smith, 1994). A playa depth of 0.25 meters was used based on average cropland and grassland playa depths from a previous SHP study (Luo et al. 1997). Cotton seed planting rate was assumed to be 65,000 seeds per acre (0.4047 hectares). Neonicotinoid extraction from treated seeds used to grow cotton revealed an average of $0.25 \mathrm{mg}$ of active ingredient (neonicotinoid) per seed. Based on these assumptions, it was estimated that $2.23 \mathrm{~kg}$ of active ingredient would be present in a 55.5 hectare watershed, due to cotton seed treatment. Because all of the analyzed neonicotinoids have a water solubility greater than 100 ppm (for example, thiamethoxam $=4.1$ $\mathrm{g} / \mathrm{L}$ and imidacloprid $=0.61 \mathrm{~g} / \mathrm{L}$ ), five percent of the applied chemical (111 $\mathrm{g}$ in this case) in the watershed is assumed to be in the runoff (Parker et al. 1995). In this situation, with a 6.3 hectare playa (0.25 meters deep), the resulting maximum neonicotinoid concentration due to seed treatments would be $7.1 \mathrm{ng} / \mathrm{mL}(\mathrm{ppb})$.

Playa Samples

Of the 21 playas sampled, ten had at least one quantifiable neonicotinoid present, three 322 of which were classified as grassland (range) playas, two were urban, and the remaining five were 323 cropland playas (Table 3). Overall frequency of detection was 48\%, regardless of playa 
324 classification. Only three playas (two cropland and one grassland) contained more than one

325 neonicotinoid. Total neonicotinoid concentrations ranged from $0.2 \mathrm{ppb}$ to $4.2 \mathrm{ppb}$ (both in

326 grassland playas). Average total neonicotinoid concentration was $0.7 \pm 0.6 \mathrm{ppb}$ in grassland

327 playas, $1.0 \pm 0.4 \mathrm{ppb}$ in cropland playas, and $1.1 \pm 0.9 \mathrm{ppb}$ in urban playas. Overall, there was no

328 statistically significant difference in total neonicotinoid concentration among playa type.

329 Thiamethoxam was the neonicotinoid most frequently detected, occurring in eight of the

330 sampled playas. Four of the samples containing thiamethoxam were from cropland playas, with

331 two each from grassland and urban playas. Clothianidin was detected in four playas, two

332 classified as cropland and two classified as grassland. Imidacloprid was detected solely in

333 cropland playas; acetamiprid was only detected once, in a grassland playa, but at a relatively high

334 concentration (3.5 ppb) compared to other neonicotinoids in our study.

335 The playa results from this study are fairly comparable to several published studies in

336 similar wetland systems. A temporal study (Main et al. 2014) determined neonicotinoid

337 concentrations in prairie pothole wetlands, which are similar hydrogeological features to playas,

338 near croplands in Canada where neonicotinoid seed treatments are also heavily used. Average

339 total neonicotinoid concentrations in the summer were below $1 \mathrm{ppb}$; maximum total

340 concentrations reached over $3 \mathrm{ppb}$ in the summer of 2012. Percent detection ranged from 16\%

341 in Fall 2012 to $91 \%$ in Spring 2013. Clothianidin was the most frequently detected, followed by

342 thiamethoxam, differing slightly from our study.

343 Another wetland study, also conducted on playa lakes in the SHP in 2005, found average

344 thiamethoxam concentrations of $3.6 \mathrm{ppb}$ and acetamiprid concentrations of $2.2 \mathrm{ppb}$ in crop and

345 grassland playas (Anderson et al. 2013). Maximum detected concentrations of thiamethoxam 
346 were $20 \mathrm{ppb}$ in cropland playas and $225 \mathrm{ppb}$ in grassland playas. Maximum acetamiprid 347 concentrations were $44 \mathrm{ppb}$ in cropland playas and $27 \mathrm{ppb}$ in grassland playas. While the average 348 concentrations are somewhat comparable to those in our study, the maxima are significantly 349 higher than those detected in this study. Frequency of detection of thiamethoxam was comparable to this study, at $31 \%$ detection in cropland playas and $25 \%$ detection in grassland 351 playas.

Studies of neonicotinoid concentrations in other aquatic systems besides dipressional wetlands, have also been conducted. A study of groundwater wells in a potato producing region in Quebec (Anderson et al. 2015) found imidacloprid in $61 \%$ of samples, with a maximum detected concentration of $6.1 \mathrm{ppb}$, or approximately 3.5 times the maximum concentration found in this study.

In samples from rivers around Sydney, Australia average concentrations of acetamiprid, clothianidin, imidacloprid, and thiamethoxam (as well as thiacloprid) were all below $0.5 \mathrm{ppb}$, and as low as $0.2 \mathrm{ppb}$ for thiamethoxam. Clothianidin concentrations were similar to our study at an average of $0.42 \mathrm{ppb}$, but all other average concentrations were nearly an order of magnitude lower. Frequency of detection ranged from $27 \%$ for thiamethoxam to $93 \%$ for imidacloprid (Sanchez-Bayo and Hyne, 2014). A 2012 study on imidacloprid concentrations in rivers and creeks in three agricultural regions of California found a maximum imidacloprid concentration of 3.29 $\mathrm{ppb}$; that was the highest reported imidacloprid concentration in the US at the time. Nineteen percent of samples exceeded the EPA chronic aquatic invertebrate exposure benchmark of 1.05 ppb at the time, and imidacloprid was detected in $89 \%$ of samples (Starner and Goh, 2012). 

chronic exposure benchmark of $0.05 \mathrm{ppb}$. The benchmark for acetamiprid is $2.1 \mathrm{ppb}$ (chronic), a number that was exceeded by the lone acetamiprid detection. The aquatic invertebrate benchmark for chronic exposure to thiamethoxam is $0.74 \mathrm{ppb} ; 3$ playa samples exceeded this metric. Overall, $28 \%$ of collected samples exceeded at least one EPA aquatic invertebrate benchmark for chronic neonicotinoid exposure. If a thiamethoxam concentration benchmark becomes available, this percentage of samples that exceed at least one benchmark will likely increase. Two of the cropland playas samples exceeded EPA benchmarks for imidacloprid acute toxicity.

When compared to results from the runoff model, the total detected neonicotinoid concentrations are all below the maximum $7.1 \mathrm{ppb}$ concentration calculated. Several playas did have total concentrations approaching that level, particularly one grassland playa with a total concentration of $4.2 \mathrm{ppb}$. Because these playas were from all classifications (one urban, one grassland, and two cropland) it is difficult to draw conclusions as to the specific source of neonicotinoids. It is interesting to note, however, that for the grassland playa with the highest total concentration (4.2 ppb), a majority of the total neonicotinoid content (83\%) was acetamiprid, which is not commonly used in the region as a seed treatment. the factors that can impact neonicotinoid concentrations in playa wetlands, such as field concentrations and runoff, are extremely variable over time. Because of the dependence of 388 playas on runoff to maintain water levels and the infrequency of major rain events in the SHP, 
389

390

391

392

393

394

395

measuring neonicotinoid concentrations through wet and dry seasons, as well as directly after major rain events, would be beneficial. In a cotton field planted with neonicotinoid-treated seeds, neonicotinoid field concentrations would naturally be higher in the late spring and early summer, corresponding to planting season. In the winter, when harvesting has been completed, and fields are not in use, neonicotinoid field concentrations would likely be lower (Hladik et al. 2018). Other seasonal farming practices could also have an impact on the availability of neonicotinoids in runoff.

Neonicotinoid concentrations may also vary annually; it is likely that concentrations would vary between extremely dry and extremely wet years, as amount of runoff increases or decreases, or as water volume is lost in playas due to evaporation and aquifer recharge. Years with unusually high numbers of cotton pests, may also cause variation in concentrations as reapplication may be necessary. Due to these possible environmental sources of variation, an accurate depiction of neonicotinoid concentrations in playa wetlands is not possible without some temporal sampling.

\section{Conclusions}

Neonicotinoid seed treatments appear to be an acceptable means for a more localized application of insecticides to cotton plants. Presence of imidacloprid and thiamethoxam in the leaves of plants grown from treated seeds indicates that plants successfully translocate the active ingredient through vascular tissue. Claims that seed treatments protect plants for 3-4 weeks post-planting appear to be valid based on concentrations of active ingredient present in leaf tissue and may even be an underestimation. Although seed treatments may reduce the total 
411 amount of active ingredient applied to a field and may reduce other sources of non-target

412 exposure (such as pesticide drift), neonicotinoid residues were present in the test fields, even 413150 days after planting.

414 The presence of neonicotinoids in soil raises concern over the potential for agricultural 415 runoff into water bodies, particularly in the SHP where playa wetlands are common. Analysis of 416 water samples from 21 playa wetlands showed the presence of neonicotinoids in nearly half of 417 all samples. Twenty-eight percent of collected samples had concentrations of at least one 418 neonicotinoid in exceedance of the EPA Aquatic Invertebrate Benchmarks for chronic exposure. 419 This suggests that neonicotinoids in playa wetlands have the potential to affect 420 macroinvertebrate community densities and structure. Additional temporal monitoring of playa 421 neonicotinoid concentrations coupled with invertebrate sampling would allow for any possible 422 correlations between neonicotinoid concentrations and macroinvertebrate density (Van Dijk et 423 al. 2013). It may also allow for the identification of any multi-generational or delayed effects. 
426

427

428

429

430

431

432

433

434

435

436

437

438

439

440

441

442

443

444

445

446

447

448

449

450

451

452

453

454

\section{References}

Anderson J, Dubetz C, Palace V. 2015. Neonicotinoids in the Canadian aquatic environment: A literature review on current use products with a focus on fate, exposure, and biological effects. Science of the Total Environment 505: 409-422.

Anderson JT, Smith LM. 1999. Carrying capacity and diel use of managed playa wetlands by nonbreeding waterbirds. Wildlife Society Bulletin 27(2): 281-291.

Anderson TA, Salice CJ, Erickson RA, McMurry ST, Cox SB, Smith LM. 2013. Effects of landuse and precipitation on pesticides and water quality in playa lakes of the southern high plains. Chemosphere 92(1): 84-90.

Balfour NJ, Carreck NL, Blanchard HE, Ratnieks FLW. 2016. Size matters: Significant negative relationship between mature plant mass and residual neonicotinoid levels in seedtreated oilseed rape and maize crops. Agriculture, Ecosystems \& Environment 215:8588.

Belden JB, Hanson BR, McMurry ST, Smith LM, Haukos DA. 2012. Assessment of the effects of farming and conservation programs on pesticide deposition in high plains wetlands. Environmental Science \& Technology 4: 3424-3432.

Bonmatin J-M, Giorio C, Girolami V, Goulson D, Kreutzweiser DP, Krupke C, Liess M, Long E, Marzaro M, Mitchell EAD, Noome DA, Simon-Delso N, Tapparo A. 2015. Environmental fate and exposure; neonicotinoids and fipronil. Environmental Science and Pollution Research 22:35-67.

Elbert A, Haas M, Springer B, Thielert W, Nauen N. 2008. Applied aspects of neonicotinoid uses in crop protection. Pest Management Science 64: 1099-1105. 
455

456 Finnegan MC, Baxter LR, Maul JD, Hanson ML, Hoekstra PF. 2017. Comprehensive 457 characterization of the acute and chronic toxicity of the neonicotinoid insecticide 458 thiamethoxam to a suite of aquatic primary producers, invertebrates, and fish.

460

461 Girolami V, Mazzon L, Squartini A, Mori N, Marzaro M, Di Bernardo A, Greatti M, Giorio C, 462 Environmental Toxicology and Chemistry 36: 2838-2848.

465

Goulson D. 2013. An overview of the environmental risks posed by neonicotinoid insecticides. Tapparo A. 2009. Translocation of neonicotinoid insecticides from coated seeds to seedling guttation drops: a novel way of intoxication for bees. Journal of Economic

468

469

Greenberg SM, Liu TX, Adamczyk JJ. 2009. Thrips (Thysanoptera: Thripidae) on cotton in the

470

471 lower Rio Grande valley of Texas: species composition, seasonal abundance, damage,

472

473

Hallmann CA, Foppen RPB, van Turnhout CAM, de Kroon H, Jongejans E. 2014. Declines in 474 insectivorous birds are associated with high neonicotinoid concentrations. Nature 511:

476

477 Haukos DA, Smith LM. 1994. The importance of playa wetlands to bidiversity of the southern high plains. Landscape and Urban Planning 23: 83-98.

479

Hladik ML, Kolpin DW, Kuivila KM. 2014. Widespread occurrence of neonicotinoid insecticides in streams in a high corn and soybean producing region, USA. Environmental 483 
484 Hladik ML, Corsi SR, Kolpin DW, Baldwin AK, Blackwell BR, Cavallin JE. 2018. Year-round 485 presence of neonicotinoid insecticides in tributaries to the Great Lakes, USA. Environmental Pollution 235:1022-1029.

487

Hodgson E, Krupke C. 2012. Insecticidal Seed Treaments can Harm Honey Bees. Integrated Crop Management News 6 April 2012.

490

491

492

493

Huff Hartz KE, Edwards TM, Lydy MJ. 2017. Fate and transport of furrow-applied granular tefluthrin and seed-coated clothianidin insecticides: Comparison of field-scale observations and model estimates. Ecotoxicology 26:876-888.

494

495

Jeschke P, Nauen R, Schindler M, Elbert A. 2011. Overview of the status and global strategy for 496 neonicotinoids. Journal of Agricultural and Food Chemistry 59:2897-2908.

497

498

499

500

Jones A, Harrington P, Turnbull G. 2014. Neonicotinoid concentrations in arable soils after seed treatment applications in preceding years. Pest Management Science 70:1780-

501

502

503 1784.

504

505

506

Luo HR, Smith LM, Allen BL, Haukos DA. 1997. Effects of sedimentation on playa wetland 507

Maienfisch P, Angst M, Brandl F, Fischer W, Hofer D, Kayser H, Kobel W, Rindlisbacher A, Senn R, Steinemann A, Widmer H. 2001. Chemistry and biology of thaimethoxam: a second generation neonicotinoid. Pest Management Science 57:906-913. 
512 Main AR, Headley JV, Peru KM, Michel NL, Cessna AJ, Morrissey CA. 2014. Widespread use and 513 frequent detection of neonicotinoid insecticides in wetlands of Canada's prairie $514 \quad$ pothole region. Plos One 9(3):e101400.

515

516 Maxim L, van der Sluijs J. 2013. Seed-dressing systemic insecticides and honeybees, in Late lessons from early warnings: science, precaution, innovation. European Environment Agency (EEA) pp. 369-406.

519

Morrissey CA, Mineau P, Devries JH, Sanchez-Bayo F, Liess M, Cavallaro MC, Liber K. 2015. Neonicotinoid contamination of global surface waters and associated risk to aquatic invertebrates: A review. Environmental International 74:291-303.

523

Nauen R, Ebbinghaus-Kintscher U, Salgado VL, Kaussmann M. 2003. Thiamethoxam is a neonicotinoid precursor converted to clothianidin in insects and plants. Pesticide Biochemistry and Physiology 76:55-69.

527

528

529

530

531

532

Samson-Robert O, Labrie G, Chagnon M, Fournier V. 2017. Planting of neonicotinoid-coated 535 corn raises honey bee mortality and sets back colony development. PeerJ 5:e3670

Parker RD, Jones RD, Nelson HP. 1995. GENEEC: A Screening Model for Pesticide Environmental Exposure Assessment.,in Proceedings of the International Exposure Symposium on Water Quality Modeling; American Society of Agricultural Engineers pp. 485-490; Orlando, Florida.

\section{9}


540 Sanchez-Bayo F, Hyne RV. 2014. Detection and analysis of neonicotinoids in river waters 541 development of a passive sampler for three commonly used insecticides. Chemosphere

542

543

544

545

546

547

548

549

550

551

552

553

554

555

556

557

558

559

560

561

562

563

564

565

566

567

568 99:143-151.

Sánchez-Bayo F, Goka K, Hayasaka D. 2016. Contamination of the aquatic environment with neonicotinoids and its implication for ecosystems. Frontiers in Environmental Science $4: 71$.

Sharma S, Singh B. 2014. Metabolism and persistence of imidacloprid in different types of soils under laboratory conditions. International Journal of Environmental Analytical Chemistry 94(11):1100-1112.

Simon-Delso N, Amaral-Rogers V, Belzunces LP, Bonmatin JM, Chagnon M, Downs C, Furlan L, Gibbons DW, Giorio C, Girolami V, Goulson D, Kreutzweiser DP, Krupke CH, Liess M, Long E, McField M, Mineau P, Mitchell EAD, Morrissey CA, Noome DA, Pisa L, Settele J, Stark JD, Tapparo A, Van Dyck H, Van Praagh J, Van der Sluijs JP, Whitehorn PR, Wiemers M. 2015. Systemic insecticides (neonicotinoids and fipronil): trends, uses, mode of action and metabolites. Environmental Science and Pollution Research 22:5-34.

Starner K, Goh KS. 2012. Detections of the neonicotinoid insecticide imidacloprid in surface waters of three agricultural regions of California, USA, 2010-2011. Bulletin of Environmental Contaimination and Toxicology 88:316-321.

Sur R, Stork A. 2003. Uptake, translocation and metabolism of imidacloprid in plants. Bulletin of Insectology 56:35-40.

Tomizawa M, Casida JE. 2005. Neonicotinoid insecticide toxicology: mechanisms of selective action. Annual Review of Pharmacological Toxicology. 45:247-268. 
570 Tsvetkov N, Samson-Robert O, Sood K, Patel HS, Malena DA, Gajiwala PH, Maciukiewicz P, 571 Fournier V, Zayed A. 2017. Chronic exposure to neonicotinoids reduces honey bee 572 health near corn crops. Science 356(6345):1395-1397.

573

574 US EPA, Aquatic Life Benchmarks. [Online]. [Available at: https://www.epa.gov/pesticide575 science-and-assessing-pesticide-risks/aquatic-life-benchmarks-and-ecological-risk]. $576 \quad$ [Accessed 9 March 2019].

577

Van Dijk TC, Van Staalduinen MA, Van der Sluijs JP. 2013. Macro-invertebrate decline in surface water polluted with imidacloprid. PLOS ONE 8(5):e62374.

580

581

Wettstein FE, Kasteel R, Garcia Delgado MF, Hanke I, Huntscha S, Balmer ME, Poiger T, 582 Bucheli TD. 2016. Leaching of the neonicotinoids thiamethoxam and imidacloprid from sugar beet seed dressings to subsurface tile drains. Journal of Agricultural and Food Chemistry 64:6407-6415. 


\section{Table 1 (on next page)}

Mean ${ }^{1}$ cotton leaf tissue concentrations of thiamethoxam and imidacloprid ( \pm standard error of the mean) as determined by $\mathrm{HPLC}^{2}$ in 2014. 
1 Table 1. Mean ${ }^{1}$ cotton leaf tissue concentrations of thiamethoxam and imidacloprid ( \pm 2 standard error of the mean) as determined by HPLC ${ }^{2}$ in 2014.

\begin{tabular}{|l|c|c|c|}
\hline Site (planting date) & $\begin{array}{c}\text { Sampling Date } \\
\text { (days post planting) }\end{array}$ & $\begin{array}{c}\text { Thiamethoxam } \\
\text { (ng/g) }\end{array}$ & $\begin{array}{c}\text { Imidacloprid }^{\mathbf{3}} \\
\text { (ng/g) }\end{array}$ \\
\hline Chillicothe (5/19) & $6 / 4(15)$ & $2,704 \pm 836$ & $2,313 \pm 406$ \\
\hline & $6 / 19(28)$ & $72 \pm 39$ & $180 \pm 91$ \\
\hline Lamesa (5/17) & $6 / 10(23)$ & $6,840 \pm 2,912$ & $1,783 \pm 600$ \\
\hline & $6 / 18(30)$ & $218 \pm 147$ & $247 \pm 136$ \\
\hline Wall (5/23) & $6 / 18(25)$ & $3,234 \pm 317$ & $1,436 \pm 320$ \\
\hline & $6 / 23(30)$ & $18 \pm 13$ & $5.0 \pm 0$ \\
\hline Halfway (5/6) & $6 / 11(35)$ & $18 \pm 13$ & $8.0 \pm 3.3$ \\
\hline Kress (5/13) & $6 / 3(20)$ & $10,618 \pm 3,365$ & $15,100 \pm 4,885$ \\
\hline
\end{tabular}

3

4

5

6

7

8

9

10

${ }^{1}$ We used the leaf quantitation limit $(5 \mathrm{ng} / \mathrm{g})$ for non-detect samples in calculating the mean.

${ }^{2}$ The MDL for thiamethoxam and imidacloprid in leaf tissue extracts was $2 \mathrm{ng} / \mathrm{g}$.

${ }^{3}$ Based on the locations sampled twice and assuming losses followed a linear relationship, the estimated thiamethoxam and imidacloprid dissipation half-lives in cotton leaves were 4.3 days and 4.5 days, respectively. 


\section{Table 2 (on next page)}

Mean soil concentrations of thiamethoxam and imidacloprid ( \pm standard error of the mean) as determined by HPLC ${ }^{1}$ in 2014. 
1 Table 2. Mean soil concentrations of thiamethoxam and imidacloprid ( \pm standard error of the 2 mean) as determined by HPLC ${ }^{1}$ in 2014.

\begin{tabular}{|l|c|c|c|}
\hline Site (planting date) & $\begin{array}{c}\text { Sampling Date } \\
\text { (days post planting) }\end{array}$ & $\begin{array}{c}\text { Thiamethoxam } \\
\text { (ng/g) }\end{array}$ & $\begin{array}{c}\text { Imidacloprid } \\
\text { (ng/g) }\end{array}$ \\
\hline Chillicothe (5/19) & $6 / 4(15)$ & $20 \pm 8.8$ & $35 \pm 13$ \\
\hline & $6 / 19(28)$ & $33 \pm 17$ & $28 \pm 12$ \\
\hline Lamesa (5/17) & $6 / 10(23)$ & $65 \pm 29$ & $162 \pm 144$ \\
\hline & $9 / 29(134)$ & $4.9 \pm 0.5$ & $5.2 \pm 4.0$ \\
\hline Wall (5/23) & $6 / 18(25)$ & $14 \pm 5.2$ & $16 \pm 2.1$ \\
\hline & $9 / 29(128)$ & $9.4 \pm 1.2$ & $8.2 \pm 2.5$ \\
\hline Halfway (5/6) & $10 / 1(147)$ & $20 \pm 4.5$ & $98 \pm 47$ \\
\hline Kress (5/13) & $10 / 1(140)$ & $12 \pm 1.2$ & $38 \pm 34$ \\
\hline
\end{tabular}

$3{ }^{1}$ The MDLs for thiamethoxam and imidacloprid in soil extracts were $1.0 \mathrm{ng} / \mathrm{g}$ and $0.5 \mathrm{ng} / \mathrm{g}$, 4 respectively. 


\section{Table 3 (on next page)}

Neonicotinoids in playa water samples collected in 2014. Frequency of detection, as well as low and high concentrations for individual neonicotinoids are indicated. 
1 Table 3. Neonicotinoids in playa water samples collected in 2014. Frequency of detection, as

2 well as low and high concentrations for individual neonicotinoids are indicated.

3

\begin{tabular}{|c|c|c|c|c|c|}
\hline $\begin{array}{l}\text { Playa } \\
\text { Type }\end{array}$ & & Thiamethoxam & Imidacloprid & Acetamiprid & Clothianidin \\
\hline \multirow[t]{3}{*}{ Urban } & 4 sites & $50 \%$ & $0 \%$ & $0 \%$ & $0 \%$ \\
\hline & {$[$ Low $]$} & $0.3 \mathrm{ng} / \mathrm{mL}$ & ND & ND & ND \\
\hline & [High] & $3.8 \mathrm{ng} / \mathrm{mL}$ & ND & ND & ND \\
\hline \multicolumn{6}{|c|}{ Mean [Total Neonicotinoids] \pm standard error $=1.1 \mathrm{ng} / \mathrm{mL} \pm 0.9$} \\
\hline \multirow[t]{3}{*}{ Crop } & 10 sites & $40 \%$ & $20 \%$ & $0 \%$ & $20 \%$ \\
\hline & {$[$ Low $]$} & $0.6 \mathrm{ng} / \mathrm{mL}$ & $1.1 \mathrm{ng} / \mathrm{mL}$ & ND & $0.1 \mathrm{ng} / \mathrm{m}$ \\
\hline & [High] & $3.1 \mathrm{ng} / \mathrm{mL}$ & $1.8 \mathrm{ng} / \mathrm{mL}$ & ND & $1.1 \mathrm{ng} / \mathrm{mL}$ \\
\hline
\end{tabular}

Mean [Total Neonicotinoids] \pm standard error $=1.0 \mathrm{ng} / \mathrm{mL} \pm 0.4$

$\begin{array}{rrrrrr}\text { Range } & 7 \text { sites } & 29 \% & 0 \% & 14 \% & 29 \% \\ & {[\text { Low }]} & 0.5 \mathrm{ng} / \mathrm{mL} & \mathrm{ND} & 3.5 \mathrm{ng} / \mathrm{mL} & 0.2 \mathrm{ng} / \mathrm{mL} \\ & {[\text { High }]} & 0.6 \mathrm{ng} / \mathrm{mL} & \mathrm{ND} & 3.5 \mathrm{ng} / \mathrm{mL} & 0.2 \mathrm{ng} / \mathrm{mL}\end{array}$

Mean [Total Neonicotinoids] \pm standard error $=0.7 \mathrm{ng} / \mathrm{mL} \pm 0.6$

$4 \overline{\mathrm{ND}}=$ not detected. The limit of detection for neonicotinoids in water was approximately 0.05

$5 \mathrm{ng} / \mathrm{mL}$. The limit of quantitation was $0.1 \mathrm{ng} / \mathrm{mL}$. 
Figure 1

Mean (for all locations) leaf tissue concentrations of thiamethoxam and imidacloprid compared with number of days since planting.

Error bars are the standard error of the mean. 




